膀胼腫瘍の統計学的研究

一多变量解析による予後因子の検討一

\begin{tabular}{|c|c|c|c|}
\hline \multirow{4}{*}{$\begin{array}{c}\text { 名古屋大学医学部泌尿器科学教室 } \\
\text { (主任僌授) }\end{array}$} & 高 & \pm & 宗 \\
\hline & 村 & 瀬 & 達 \\
\hline & $\equiv$ & 宅 & 弘 \\
\hline & $\exists$ & 矢 & 英 \\
\hline $\begin{array}{c}\text { 名古屋市立大学医学部公衆衛生学教室 } \\
\text { (野良之教授) }\end{array}$ & 大 & 野 & 良 \\
\hline $\begin{array}{c}\text { 名古屋大学医学部予防医学教室 } \\
\text { (主任 : 青木国雄教授) }\end{array}$ & . & 島 & 信 \\
\hline
\end{tabular}

\title{
STATISTICAL STUDY ON TUMORS OF THE URINARY BLADDER
} -Multivariate Analyses of Prognostic Determinants for Bladder Cancer-

\author{
Munehisa Takashi, Tatsuro Murase, Koji Miyake and Hideo Mitsuya \\ Department of Urology, Nagoya University School of Medicine \\ (Director: Prof. H. Mitsuya) \\ Yoshiyuki Ohno \\ Department of Public Health, Medical School, Nagoya City University \\ (Director: Prof. Y. Ohno) \\ Nobuyuki Hamajima \\ Department of Preventive Medicine, Nagoya University School of Medicine \\ (Director: Prof. K. Aoki)
}

In order to evaluate the relative importance of clinicopathological factors for survival of patients with urinary bladder cancer, two multivariate analyses were undertaken on 121 patients initially treated at Nagoya University Hospital from 1973 to 1982. The factors included in the analyses were sex, age, symptoms, interval between the onset of symptoms and first consultation, and six tumor characteristics such as location, size, number, shape, grade and stage.

Using Hayashi's quantification theory (type II), the authors found that the three major determinants of prognostic importance were stage, tumor size and grade in this order. At the same time multiple regression analysis demonstrated that approximately 40 percent of variability in the prognosis could be explained by stage alone. When the remaining nine factors listed above were included, the accuracy increased only to about 50 percent, indicating that stage is the single major determinant of prognostic significance in urinary bladder cancer. Grade seemed to be less important for prognosis in multiple regression analysis, since grade was closely associated with stage, with a significant positive correlation coefficient of 0.689 . The contribution of stage to survival was relatively large for the first and third postoperative years, and decreased slightly thereafter. As the contribution of stage decreased, the prognostic importance of grade and tumor location tended to increase.

The authors believe that the overall results of the present multivariate analyses confirm the prior clinical impressions both quantitatively and objectively. It is therefore concluded that improved prognosis of patients with bladder cancer requires accurate staging of the tumors, together with selection of appropriate treatment procedures based on this staging.

要旨：1973年から1982年までに名古屋大学医学部附属病院泌尿器科において初回入院治療を施行した膀 胱癌患者121例を対象に, 多変量解析法（数量化理論II類招よび重回帰分析）を用いて，予後因子の相対 
的重要度を評価した。分析には性・年齢・症状・初発症状から受診までの期間・腫瘍の発生部位・大き さ・数・形態・異型度・深達度の 10 因子を用いた。

数量化理論 II 類による結果から深達度, 腫腸の大きさ, 異型度の三者が予後因子として重要であるこ とが明らかになった。 また, 重回帰分析の結果では, 深達度の予後に対する寄与率は約 $40 \%$ あ゙あ, 深 達度に他の 9 因子を加えても寄与率は約 $50 \%$ をで増加するにすぎず, 膀胱癌では深達度が最も重要な予 後因子であることが示唆された。術後 1 年・ 3 年の時点では深達度の予後に対する相対的関与度は大き いが, 術後の観察期間が長くなるにつれて深達度の関与度は次第に小さくなり，一方異型度・部位の関 与度が大きくなる傾向がみられた。

以上，二つの多変量解析の成績は同様の傾向を示したが，これらの結果は従来与えられている臨床的 印象をさらに計量的客観的に明示したものとして意義がある.膀脱癌患者の予後を向上させるためには, 深達度診断の精度を高めることと深達度診断に基いて適切な治療法を選択することが重要であると考え られる。

\section{緒言}

膀胧癌患者の予後にとって, Jewett $ら^{122)}$ の指摘以 来, 腫瘍の深達度が重要であることは知られているが, 宿主, 腫瘍拈よび治療の諸因子が相互に複雑に関与し ているものと考号れる。著者らはこれまでに, 初回 治療を施した膀胼腫瘍症例を対象に, 臨床的・病理学 的因子の特性 ${ }^{3)}$ とれらと生存率との関係 ${ }^{4)}$ とついて 検討してきた。その結果, 性・年齢・膀胼刺激症状 腫湯発生部位・大きさ・形態・組織型・異型度・深達 度・発育様式が予後を左右する重要な因子であり, 初 発症状から受診までの期間や腫瘍数は予後指標として 意義が少ないことを報告した。一般に臨床的・病理学 的各因子はそれぞれ相互に密接に関連しあっているた め, そのままでは各因子独自の予後に対する関与度を 十分に評価することは困難である。 そこで今回は, 膀 胱癌患者の予後に対する臨床的・病理学的因子各々の 相対的関与度を明らかにするために多变量解析法を用 いて検討したので，ここに報告する。

\section{対象および方法}

\section{1. 対象}

1973年から1982年をでの 10 年間に, 名古屋大学医学 部附属病院泌尿器科で初回入院治療を施した膀胱原発 性上皮性腫瘍 228 症例 ${ }^{3)}$ のちち, 後述の各項目に欠損值 がなく, かつ術後 1 年以上経過を観察しえた 121 症例 （男子99例・女子 22 例，平均年齢男子 59.9 歳・女子 59.7 歳）を分析対象とした。これら症例の各因子別頻度分 布の詳細については既に述べたと招りである31. 分析 対象症例数は, 観察期間が長くなるにつれて减少し, 術後 3 年・ 5 年・ 7 年にてそれぞれ 90 例・73例・59例 である。

\section{2. 方法}

上記症例の臨床的・病理学的因子を 10 要因（アイテ ム)・30区分（カテゴリー）に分類した（Table 1). 内 視鏡的所見拉よび組織学的所見は膀胱癌取扱い規約 ${ }^{5}$

Table 1 分析に用いた要因とその区分

\begin{tabular}{|c|c|}
\hline アイテム & カテゴリー \\
\hline 1：性別 & $\begin{array}{l}1 \text { 男 } \\
2 \text { 女 }\end{array}$ \\
\hline $2:$ 年齢 & $\begin{array}{ll}1 & 49 \text { 歳以下 } \\
2 & 50-69 \text { 歳 } \\
3 & 70 \text { 歳以上 }\end{array}$ \\
\hline 3 : 症状 & $\begin{array}{l}1 \text { 膀胱刺激症状なし } \\
2 \text { 膀胱刺激症状あり }\end{array}$ \\
\hline 4:症状発現から受診 & 11 力月以内 \\
\hline までの期間 & 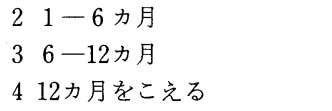 \\
\hline 5 : 腫瘍発生部位 & $\begin{array}{l}1 \text { 尿管口近傍領域 } \\
2 \text { その他の部位 }\end{array}$ \\
\hline 6：主腫瘍の大きさ & $\begin{array}{ll}1 & 1 \mathrm{~cm} \text { 以下 } \\
2 & 1.1-3 \mathrm{~cm} \\
3 & 3.1-5 \mathrm{~cm} \\
4 & 5.1 \mathrm{~cm} \text { 以上 }\end{array}$ \\
\hline 7 : 腫痬数 & $\begin{array}{l}1 \text { 単発性 } \\
2 \text { 多発性 }\end{array}$ \\
\hline 8: 腫瘍の形態 & $\begin{array}{l}1 \text { 乳頭状 } \\
2 \text { 非乳頭状 }\end{array}$ \\
\hline $9:$ 組織型 - 異型度 & $\begin{array}{l}1 \mathrm{TCC} \cdot \mathrm{G} 1 \text { と乳頭腫 } \\
2 \mathrm{TCC} \cdot \mathrm{G} 2 \\
3 \mathrm{TCC} \cdot \mathrm{G} 3 \text { と } \mathrm{TCC} \text { 以外の癌 }\end{array}$ \\
\hline 10 : 組織学的深達度 & $\begin{array}{l}1 \text { pTa } \\
2 \text { pT1 } \\
3 \text { pT2 } \\
4 \text { pT3a } \\
5 \text { pT3b } \\
6 \text { pT4 }\end{array}$ \\
\hline
\end{tabular}

TCC : 移行上皮癌 
に従ったが，とくに腫瘍発生部位については両側の尿 管口から外側あるいは背側にかけての尿管口近傍領 域3に注目し，この部位を独立して扱った。

各因子間の相互関係は単相関係数を求めて検討し た。 術後 1 年・ 3 年・ 5 年・ 7 年の各時点における生 死を, 外的基準变数あるいは従属変数として多变量解 析を行なった. 多変量解析法は林の数量化理論 II 類と 重回㷌分析(6) 8)である. 解析には名古屋大学大型計算 機センターに怙いて, SPSS (Statistical Package for the Social Science $)^{910)}$ を用いた。

\section{結 果}

\section{1. 各因子間の単相関係数}

各因子間の単相関係数を Table 2 に示した。

有意水準 $0.1 \%$ 以下で，＜深達度 >と<症状・腫疸発 生部位・大きさ・形態・異型度 $>$ の間，<異型度 $>$ と $<$ 症状・腫瘍発生部位・大きさ・形態 $>$ の間, <形態 $>$ と<症状・畽瘍発生部位・大きさ>の間に有意の正相 関がみられた。
有意水準 $1 \%$ 以下で有意の正相関を示したものは $<$ 年齢 $>$ と $<$ 腫瘍数 $>$ の間, <症状 $>$ と<部位 $>$ の間, 〈大きさ $>$ とく受診までの期間 $>$ の間であった。

有意水準 $5 \%$ 以下では，＜年龄>と<受診までの期 間>の間に有意の負相関がみられ，<年齢>と<部 位 $>$ の間, <症状 $>$ と<大ささ >の間, <部位 $>$ と<大 きさ>の間で各々正相関がみられた。

\section{2. 林の数量化理論 II 類による成績}

術後 1 年・ 3 年・ 5 年・ 7 年の各時点に拈ける各因 子の偏相関係数とその順位を Table 3 に示した。偏相 関係数は，他因子の影響を除いて各因子の予後に対す る“重み”を示す一つの指標である。術後 1 年目の予 後に対する偏相関係数は, 大きい順に深達度 $(0.564)$, 大きさ $(0.233)$, 異型度 $(0.216)$, 形態 (0.158) であ る. 術後 3 年目の予後には, 深達度 $(0.446)$, 大きさ (0.376), 珄 (0.275), 異型度 (0.263) の順である. 術後 5 年目では, 大ささ $(0.422)$, 深達度 $(0.407)$, 異型度 $(0.275)$, 部位 $(0.259)$ の順, 術後 7 年目では,

Table 2 各因子間の単相関係数

\begin{tabular}{|c|c|c|c|c|c|c|c|c|c|c|}
\hline 因 子 & 1. & 2 . & 3 . & 4. & 5 . & 6. & 7 . & 8 . & 9 . & 10. \\
\hline 1. 性 & 1.000 & & & & & & & & & \\
\hline 2. 年齢 & -0.080 & 1.000 & & & & & & & & \\
\hline 3. 膀胱刺激症状 & 0.121 & 0.049 & 1.000 & & & & & & & \\
\hline 4. 受診までの期間 & 0.054 & $-0.148^{*}$ & -0.024 & 1.000 & & & & & & \\
\hline 5. 部位 & -0.028 & $0.149^{*}$ & $0.196^{* *}$ & -0.025 & 1.000 & & & & & \\
\hline 6. 大きさ & 0.088 & -0.001 & $0.128^{*}$ & $0.221^{* *}$ & $0.167^{*}$ & 1.000 & & & & \\
\hline 7. 数 & 0.044 & $0.201^{* *}$ & 0.045 & 0.001 & 0.118 & -0.048 & 1.000 & & & \\
\hline 8. 形態 & 0.080 & 0.008 & $0.369^{* * *}$ & 0.045 & $0.312^{* * *}$ & $0.261^{* * *}$ & 0.035 & 1.000 & & \\
\hline 9. 異型度 & 0.028 & 0.105 & $0.339^{* * *}$ & 0.051 & $0.258^{* * *}$ & $0.327^{* * *}$ & 0.076 & $0.685^{* * *}$ & 1.000 & \\
\hline 10. 深達度 & 0.053 & 0.007 & $0.392^{* * *}$ & 0.052 & $0.343^{* * *}$ & $0.484^{* * *}$ & -0.067 & $0.721^{* * *}$ & $0.689^{* * *}$ & 1.000 \\
\hline
\end{tabular}

Table 3 数量化理論 II 類による偏相関係数とその順位

\begin{tabular}{|c|c|c|c|c|}
\hline $\begin{array}{l}\text { 説明変数 } \\
\text { (例数) }\end{array}$ & $\begin{array}{c}\text { 術後 } 1 \text { 年. (順位) } \\
(\mathrm{n}=121)\end{array}$ & $\begin{array}{c}\text { 術後 } 3 \text { 年 (順位) } \\
(\mathrm{n}=90)\end{array}$ & $\begin{array}{c}\text { 術後 } 5 \text { 年 (順位) } \\
(\mathrm{n}=73)\end{array}$ & $\begin{array}{c}\text { 術後 } 7 \text { 年 (順位) } \\
(\mathrm{n}=59)\end{array}$ \\
\hline 1. 性 & $0.118(5)$ & $0.275(3)$ & $0.190(5)$ & $0.128(7)$ \\
\hline 2. 年齢 & $0.105(7)$ & $0.219(6)$ & $0.184(7)$ & $0.129(6)$ \\
\hline 3. 膀脱刺激症状 & $0.034(10)$ & $0.182(8)$ & $0.119(8)$ & $0.100(9)$ \\
\hline 4. 受診交での期間 & $0.109(6)$ & $0.206(7)$ & $0.190(6)$ & $0.076(10)$ \\
\hline 5. 部位 & $0.102(8)$ & $0.225(5)$ & $0.259(4)$ & $0.325(4)$ \\
\hline 6. 大きさ & $0.233(2)$ & $0.376(2)$ & $0.422(1)$ & $0.399(1)$ \\
\hline 7. 数 & $0.063(9)$ & $0.039(10)$ & $0.030(10)$ & $0.103(8)$ \\
\hline 8. 形態 & $0.158(4)$ & $0.088(9)$ & $0.040(9)$ & $0.157(5)$ \\
\hline 9. 異型度 & $0.216(3)$ & $0.263(4)$ & $0.275(3)$ & $0.369(3)$ \\
\hline 10. 深達度 & $0.564(1)$ & $0.446(1)$ & $0.407(2)$ & $0.398(2)$ \\
\hline 相関比 & 0.548 & 0.598 & 0.622 & 0.598 \\
\hline
\end{tabular}


大きさ (0.399), 深達度 (0.398), 異型度 (0.369), 部位 $(0.325)$ の順である。

術後 1 年目における相関比は 0.548 , 術後 3 年目では

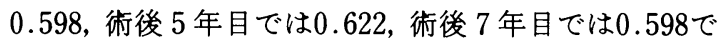
ある。相関比は 1 に近いほど, 生存群と死亡群との間 の分離の程度あるいは判別がよいことを示す指標であ る.

\section{3. 重回帰分析による成績}

術後 1 年・術後 3 年・術後 5 年・術後 7 年の時点に おける各因子の標準化偏回㷌係数, 寄与率（重相関係 数の 2 乗で，すべての分散の何パーセントが重回㷌式 で説明されるかを示す)，寄与率の増分をそれぞれ Table 4〜Table 7 に示した. 重回帰分析に推ける項目 の選定は変数増加法によっている。術後 1 年目におけ る標準化偏回帰係数は, 深達度が 0.644 と最も大きく, 深達度の予後に対する寄与率は $39.3 \%$ あるる。異型度

Table 4 予後因子についての重回帰分析結果 (術後 1 年)

\begin{tabular}{l|c|c|c}
\hline \multicolumn{1}{c|}{ 予後因子 } & 標準化偏回㷌係数 & 寄与率 & 寄与率の増分 \\
\hline 深達度 & $0.644^{* *}$ & 0.393 & 0.393 \\
異型度 & $-0.307^{* *}$ & 0.418 & 0.025 \\
年龄 & 0.102 & 0.434 & 0.016 \\
大きさ & 0.162 & 0.445 & 0.011 \\
形態 & 0.104 & 0.453 & 0.008 \\
症状 & 0.074 & 0.459 & 0.006 \\
受診までの期間 & -0.052 & 0.462 & 0.003 \\
数 & 0.054 & 0.464 & 0.002 \\
性 & -0.032 & 0.465 & 0.001 \\
部位 & 0.025 & 0.465 & 0.000 \\
\hline
\end{tabular}

${ }^{* *} \mathrm{p}<0.01$

重相関係数 $0.682 （ \mathrm{~F}=9.56, \mathrm{p}<0.01)$

Table 5 予後因子についての重回㷌分折結果 (術後 3 年)

\begin{tabular}{l|c|c|c}
\hline \multicolumn{1}{c|}{ 予後因子 } & 標準化偏回㷌係数 & 寄与率 & 寄与率の増分 \\
\hline 深達度 & $0.391^{* *}$ & 0.398 & 0.398 \\
年齢 & 0.156 & 0.432 & 0.034 \\
症状 & 0.177 & 0.460 & 0.028 \\
大きさ & 0.170 & 0.479 & 0.019 \\
性 & 0.139 & 0.496 & 0.017 \\
受診までの期間 & -0.073 & 0.500 & 0.004 \\
異型度 & 0.078 & 0.503 & 0.003 \\
部位 & 0.038 & 0.505 & 0.002 \\
数 & -0.025 & 0.505 & 0.000 \\
形態 & 0.016 & 0.505 & 0.000 \\
\hline
\end{tabular}

${ }^{* *} \mathrm{p}<0.01$

重相関係数 $0.711 （ \mathrm{~F}=8.07, \mathrm{p}<0.01)$

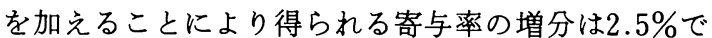

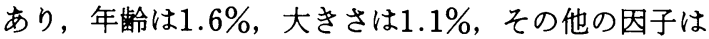
いずれも $1 \%$ 以下である.10因子全体の予後に対する 寄与率は $46.5 \%$ であるが，深達度以外の 9 因子による 寄与率の増分は $7.2 \%$ にすぎない.すなわち，10因子全 体で術後 1 年の時点に拈ける予後の $46.5 \%$ を説明する

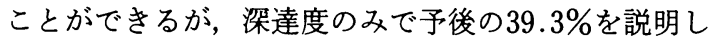
らるといらことである. 術後 3 年, 5 年の時点におけ る深達度の, 予後に対する寄与率はそれぞれ $39.8 \%$ (Table 5)，41.6\% (Table 6) で, 術後 1 年に比べる と若干大きい。また, 術後 7 年では, 深達度の奇与率 は $35.1 \%$ と対にやや小さくなるが，やはり最も重要 な予後左右因子であることには変りない，10因子全体 の寄与率は, 術後 3 年で $50.5 \%$ (Table 5 ), 術後 5 年 で53.4\% (Table 6), 術後 7 年で $47.3 \%$ (Table 7) である. 深達度以外の 9 因子による寄与率の増分は, 術後 3 年・ 5 年・ 7 年でそれぞれ $10.7 \%, 11.8 \%, 12.2 \%$

Table 6 予後因子についての重回帰分析結果 (術後 5 年)

\begin{tabular}{l|c|c|c}
\hline \multicolumn{1}{c|}{ 予後因子 } & 標準化偏回㷌係数 & 寄与率 & 寄与率の増分 \\
\hline 深達度 & $0.306^{*}$ & 0.416 & 0.416 \\
年齢 & 0.136 & 0.456 & 0.040 \\
大きさ & $0.227^{*}$ & 0.479 & 0.023 \\
症状 & 0.129 & 0.500 & 0.021 \\
部位 & 0.114 & 0.509 & 0.009 \\
異型度 & 0.155 & 0.518 & 0.009 \\
受診までの期間 & -0.098 & 0.527 & 0.009 \\
性 & 0.088 & 0.534 & 0.007 \\
数 & -0.019 & 0.534 & 0.000 \\
形態 & - & - & - \\
\hline
\end{tabular}

* $\mathrm{p}<0.05$

重相関係数 $0.731 （ \mathrm{~F}=8.03, \mathrm{p}<0.01)$

Table 7 予後因子についての重回㷌分析結果 (術後 7 年)

\begin{tabular}{l|c|c|c}
\hline \multicolumn{1}{c|}{ 予後因子 } & 標準化偏回㦅係数 & 寄与率 & 寄与率の増分 \\
\hline 深達度 & 0.198 & 0.351 & 0.351 \\
異型度 & 0.241 & 0.400 & 0.049 \\
部位 & 0.168 & 0.434 & 0.034 \\
大きさ & 0.126 & 0.446 & 0.012 \\
症状 & 0.086 & 0.456 & 0.010 \\
年龄 & 0.095 & 0.462 & 0.006 \\
性 & 0.078 & 0.467 & 0.005 \\
形態 & 0.086 & 0.470 & 0.003 \\
受診までの期間 & -0.040. & 0.472 & 0.002 \\
数 & -0.039 & 0.473 & 0.001 \\
\hline
\end{tabular}

重相関係数 $0.688 （ \mathrm{~F}=4.31, \mathrm{p}<0.01)$ 
Table 8 t 値のまとめ

\begin{tabular}{l|r|r|r|r}
\hline \multicolumn{1}{c|}{ 予後因子 } & 術後 1 年 & 術後 3 年 & 術後 5 年 & 術後 7 年 \\
\hline 性 & -0.45 & 1.73 & 1.01 & 0.69 \\
年龆 & 1.39 & 1.88 & 1.45 & 0.81 \\
膀胱刺激症状 & 0.90 & 1.90 & 1.30 & 0.72 \\
受診までの期間 & -0.71 & -0.86 & -1.10 & -0.36 \\
部位 & 0.31 & 0.42 & 1.17 & 1.41 \\
大きさ & 1.89 & 1.71 & 2.12 & 0.92 \\
数 & 0.72 & -0.30 & -0.20 & -0.32 \\
形態 & 0.91 & 0.11 & - & 0.47 \\
異型度 & -2.83 & 0.62 & 1.24 & 1.47 \\
深達度 & 5.11 & 2.70 & 2.02 & 1.03 \\
\hline
\end{tabular}

$\mathrm{t}$ 值 : 偏回㷌係数/偏回㷌係数の標準誤差

にすぎない。

術後 1 年目の重相関係数は $0.682(\mathrm{~F}=9.56, \mathrm{p}$ $<0.01)$, 術後 3 年目は0.711 $(\mathrm{F}=8.07, \mathrm{p}<0.01)$, 術 後 5 年目は $0.731(\mathrm{~F}=8.03, \mathrm{p}<0.01)$, 術後 7 年目は $0.688(\mathrm{~F}=4.31, \mathrm{p}<0.01)$ であり，すべて有意である.

各術後時点に打ける各因子の偏回帰係数の $\mathrm{t}$ 值を Table 8 にまとめて示した。 $\mathrm{t}$ 值は予後に対する各因 子の関連度の有意性を示す指標で，1.96をこえる場合 が有意性のめやすとなる(有意水準 $5 \%$ )。これよりみ ると, 術後 1 年目では深達度と異型度, 術後 3 年目で は深達度, 術後 5 年目では大ささと深達度が有意であ る. 観察期間と $\mathrm{t}$ 値との関係についてみると, 観察期 間が長くなるにつれて深達度の $\mathrm{t}$ 值は次第に小さくな るが，一方，異型度の $\mathrm{t}$ 值と部位の $\mathrm{t}$ 值は次第に大き くなる傾向が認められる。これは, 術後早期には深達 度の関与が相対的に大きいが，その後は異型度と部位 の関与も大きいことを示している。

\section{考 察}

多変量解析を用いることによって，各因子独自の予 後に対する関与度を，他の因子の影響を補正して計量 的に表わすことができる。著者らは数量化理論 II 類に よって, 深達度・大きさ・異型度が術後の各時点を通 じて予後因子として重要であることを示した。 また， 重回帰分析による検討で，深達度の寄与率が術後いず れの時点でも最も高いことを明らかにした（35.1\% 〜 41.6\%). 重回帰分析による成績では, 異型度の予後 に対する関与度は予想外に小さかったが，これは，深 達度と異型度との間には強い内部相関 (Table 2参照, $\mathrm{r}=0.689$ )があるためである. 今回の二つの多変量解析 による成績は互いによく一致する結果を得たが，一方 臨床家の従来の経験的印象ともほぼ合致するもので,
これをさらに計量的客観的に示した点で意義があると いえよう。

膀胖癌患者の予後因子について，多変量解析を用い た検討はいまだ少ない.Narayana ら ${ }^{11}$ は, 膀胱癌患者 の予後因子の相対的重要度をCox の proportional hazards model ${ }^{12)}$ 用いて検討している. 初回治療群 では深達度・異型度・大きさが，また，治療歴を有す る群では，深達度と年㱓が予後に大きな影響を及ぼす

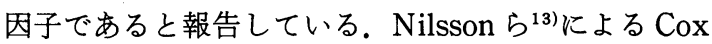
の proportional hazards model ${ }^{12)}$ 用いた検討では, 膀胼癌患者の予後にとって, 性・深達度 - 異型度・尿 中 CEA のらち深達度が最も重要であって, 異型度は 深達度に比べ予後規定因子としての意義は小さいと報 告している.

今回の多变量解析の成績から，膀脱癌患者に対する 治療法の選択や術後経過の観察に際し, 最も重要な指 標となるものは深達度であることが計量的に示された のであるが，一方臨床的観点からすれば，臨床的深達 度と病理組織学的深達度との一致率が低いという事実 があげられねばならない(14) 16)，両者の一致率につい て, Kenny ら ${ }^{17)} は 44 \%$, Richie ら ${ }^{18)}$ は34\%，小磯ら ${ }^{199}$ は $68 \%$, 岡田ら ${ }^{20)}$ は $47 \%$ と報告している。 また, 深達度 別では特に $\mathrm{pT} 2$ 症例と $\mathrm{pT}$ 症例に対する診断率が低 いとも言われている ${ }^{14) ~ 16)}$ 。この問題に関して，近年 $\mathrm{CT} \mathrm{scan}^{21) 22}$ 打よび超音波検査 ${ }^{23)}$ 26) が臨床的深達度 診断に有用であることが指摘されている。たとえば中 村ら ${ }^{26)}$ によると，経尿道的超音波検査法による深達度 診断は20例中19例に打いて組織学的深達度と一致した としている，以上より，少なくとも現時点では，深達 度についての正確な情報を得るためには CT scan・経 尿道的超音波検査の実施が大切であり, 今後さらに臨 床的深達度の診断法についての一層の開拓が必要とな 万う。

今回は，比較的容易で客観的に評価できる臨床的・ 病理学的因子に限って，多変量解析による検討を行 なったが，今後さらに宿主側因子・治療因子をも含め た多面的な予後因子についての解析が必要であると考 える。

\section{総括および結論}

（1）1973年から1982年までに，名古屋大学医学部附 属病院泌尿器科に打いて初回入院治療を施した膀朕原 発性上皮性腫場の患者のうち，術後 1 年以上追跡可能 であった121例を対象に，多变量解析法(数量化理論 II 類および重回㷌分析）を用いて，予後因子の相対的重 
要度を評価した。

（2）症状, 腫瘍の形態, 部位, 大きさ, 異型度, 深 達度の間には相互に有意の関連がみられた。

（3）数量化理論 II 類による結果から深達度, 異型度, 腫瘍の大きさが予後因子として，相対的に重要である ことが示された。

（4）重回州分析の結果によると, 術後の各時期にて 深達度の予後に対する寄与率は約 $40 \%$, また, 深達度 に他の 9 因子を加えた 10 因子の寄与率は約 $50 \%$ で, 深 達度が最も相対的に重要な予後因子であることが示さ れた。深達度の予後に対する相対的関与度は, 術後の 観察期間が長くなるにつれて若干低くなり, 異型度, 部位の関与度が高くなる傾向がみられた。

（5）以上, 二つの多変量解析の成績は一致したが, これらの結果は従来与えられている臨床的印象をさら に計量的に明示したものとして意義がある。膀胱癌患 者の治療法の決定や治療後の経過観察には, まず深達 度を重視し, 今後深達度診断の向上に努めることが重 要であると考える.

本論文の要旨は, 第34回泌尿器科中部連合総会において 発表した。

\section{文献}

1) Jewett, H.J. and Strong, G.H.: Infiltrating carcinoma of the bladder: relation of depth of penetration of the bladder wall to incidence of local extension and metastases. J. Urol., 55, 366-372, 1946.

2) Jewett, H.J.: Carcinoma of the bladder: influence of depth of infiltration on the 5-year results following complete extirpation of the primary growth. J. Urol., 67, 672-676, 1952.

3）高士宗久, 村瀬達良, 傍島 健, 伊藤 博, 青田泰 博, 安藤 正, 下地敏雄, 三宅弘治, 三矢英輔：膀 脱腫瘍の統計学的研究一臨床的 - 病理学的因子の 考察。日泌尿会誌, 75, 1452-1460, 1984.

4）高士宗久, 村瀬達良, 三宅弘治, 三矢英輔：膀胼腫 瘍の統計学的研究一臨床的 - 病理学的因子と生存 率との関係。日泌尿会誌, 76, 1323-1335, 1985.

5) 日本泌尿器科学会 -日本病理学会編：泌尿器科-病 理膀哓癌取扱い規約. 第 1 版, 金原出版, 東京, 1980.

6）富永祐民：治療効果の評価のための統計学シリー ズ(3). 多変量解析の応用. 癌と化学療法, 6,883 $-894,1979$.

7）富永祐民：多変量解析の応用. 治療効果の評価の ための実用統計学一生命表法の解説. 改訂第 1 版, p. 48-72, 蟹書房, 東京, 1982 .

8）古川俊之, 田中 博：重回帰分析. 数量化 I, II 類.
多変量解析プログラムパッケージ入門. 第 1 版, p. 17-39, p. 128-150, 医学書院, 東京, 1983.

9）司馬正次：重回㷌分析, 林の数量化理論. データ解 析入門 SPSS への招待, 第 1 版, p. 178-194, p. 206-219, 東洋経済新報社, 東京, 1977 .

10）三宅一郎, 中野嘉弘, 水野欽司, 山本嘉一郎：重回 帰分析, 数量化理論 2 類, SPSS 統計パッケージ II 解析編, 第 1 版, p. 13-40, p. 180-193, 東洋経 済新報社, 東京, 1977 .

11) Narayana, A.S., Loening, S.A., Slymen, D.J. and Culp, D.A.: Bladder cancer : factors affecting survival. J. Urol., 130, 56-60, 1983.

12) Cox, D.R.: Regression models and life tables. J.R. Statist. Soc., B, 34, 187-220, 1972.

13) Nilsson, B., Wahren, B., Esposti, P.I. and Edsmyr, F.: Prediction of survival and recurrence in bladder carcinoma. Urol. Res., 10, 109-113, 1982.

14) Skinner, D.G.: Current state of classification and staging of bladder cancer. Cancer Res., 37, 2838-2842, 1977.

15) Skinner, D.G.: Current perspectives in the management of high-grade invasive bladder cancer. Cancer, 45, 1866-1874, 1980.

16) Prout, G.R. Jr.: Classification and staging of bladder carcinoma. Bladder cancer. Bonney, W. W. and Prout, G.R. Jr. ed., AUA Monographs, Vol. 1, p. 133-146, Williams \& Wilkins, Baltimore London, 1982.

17) Kenny, G.M., Hardner, G.J. and Murphy, G.P.: Clinical staging of bladder tumors. J. Urol., 104, 720-723, 1970.

18) Richie, J.P., Skinner, D.G. and Kaufman, J.J.: Radical cystectomy for carcinoma of the bladder : 16 years of experience. J. Urol., 113, 186 $-189,1975$.

19）小磯謙吉, 大谷幹伸, 赤座英之, 中村昌平, 上野 精, 新島端夫：膀胼癌. 癌の臨床, $28,620-625$, 1982.

20）岡田清己, 野垣譲二, 斎藤忠則, 森田博人, 佐藤安 男, 岸本 孝: 膀胱腫場の深達度に関する検討. 臨 泌, 36, 845-849, 1982.

21) Lagergren, C.: Evaluation of tumour extension by whole body scanner. Urol. Res., 6, 191 -192, 1978.

22) Colleen, S., Ekeluund, L., Henrikson, H., Karp, W. and Månsson, W.: Staging of bladder carcinoma with computed tomography. Scand. J. Urol. Nephrol., 15, 109-113, 1981.

23) Boyce, W.H., Mckinney, W.M., Resnick, M.I. and Willard, J.W.: Ultrasonography as an aid in the diagnosis and management of surgical 
diseases of the pelvis: special emphasis on the genitourinary system. Ann. Surg., 184, 477 $-489,1976$.

24）白石哲朗：尿路疾患の超音波診断一膀胖腫場の浸 潤度判定に関する検討。日泌尿会誌，69，47-57, 1978.

25）金子茂男，永井信夫，松浦 健，郡健二郎，井口正 典, 南 光二, 門脇照雄, 秋山隆弘, 八竹 直, 栗
田孝：泌尿器科領域における超音波一経直腸的 超音波断層法による膀朕腫場の漫潤度判定につい て. 日泌尿会誌，69，572-577， 1978.

26) Nakamura, S. and Niijima, T.: Staging of bladder cancer by ultrasonography : a new technique by transurethral intravesical scanning. J. Urol., 124, 341-344, 1980.

（1985年 6 月 5 日受付，特別掲載） 